\title{
Synthesis of stilbene-fused 2'-hydroxychalcones and flavanones
}

\author{
İsmail Akçok, Ali Çağır* \\ Izmir Institute of Technology, Faculty of Science, Department of Chemistry, Urla-İzmir 35430, Turkey
}

\section{A R T I C L E I N F O}

\section{Article history:}

Received 25 November 2009

Available online 9 April 2010

\section{Keywords:}

Stilbene

Chalcone

Flavanone

Claisen-Schmidt reaction

Michael addition

Heck reaction

\begin{abstract}
A B S T R A C T
Synthesis of stilbene-fused chalcones and flavanones were successfully completed. Molecules were designed in a way to mimic the structural features of both "stilbene and chalcones" or "stilbene and flavanones" at the same time, and synthesized by three steps. Heck reactions of 3-bromobenzaldehyde with styrene derivatives gave corresponding $(E)$-stilbenes, which were reacted with acetophenones to furnish stilbene-fused 2'-hydroxychalcones under basic conditions. Finally, intramolecular cyclization reactions were performed to produce stilbene-fused flavanones.
\end{abstract}

(c) 2010 Elsevier Inc. All rights reserved.

\section{Introduction}

One of the goals of medicinal chemistry research and drug discovery is to develop compounds that both show desired biological activities and are easily accessible. Such compounds should be either isolated from natural resources or they should be easily synthesized in large amounts in the laboratory. To this end, the time and resources required to bring such biologically active compounds to the market can be minimized.

Flavanones (1), stilbenes (2), and chalcones (3), which are secondary metabolites of plants [1,2], are relatively simple molecules. Of significant importance, derivatives of these secondary metabolites can possess a variety of biological activities such as antitumor [3-7] antiviral [5,7], antileishmanial [8], antimalarial [9], anti-inflammatory $[3,4,7,10,11]$, antiangiogenic [12], antioxidant $[3,4,7]$ antibacterial $[3,5]$ antimitotic [13], aromatase, and metastasis inhibition [14,15] activities (Fig. 1).

Alopecurones have been isolated from the extracts of the roots of Sophora alopecuroides in 1995 by Iinuma et al., who classified these compounds as flavanostilbenes because they have both flavanone and stilbene subunits in their structure [16]. The antibacterial activities of three isolated flavanostilbenes (alopecurones A-C) against the strains of Stphylococcus aureus, which are known for their methicillin-resistant property, have also been reported [17].

In general, enzyme inhibitors are designed such that they only interact with one enzyme. Design and synthesis of pharmaceutical compounds that possess dual acting enzyme inhibitors (i.e. single compounds that inhibit two different enzymes in the same

\footnotetext{
* Corresponding author. Fax: +90 2327507509.

E-mail address: alicagir@iyte.edu.tr (A. Çağır).
}

biological environment) is desirable. Such inhibitors will require only one synthesis, one formulation and a single set of metabolism studies. Two drugs may have different pharmacokinetic rates and metabolic profiles; therefore, it might be difficult to optimally adjust their concentrations simultaneously [18]. Similarly, in cancer treatments a so-called 'combination chemotherapy' involving two different simultaneous medications, may have advantages over single-agent treatment [19]. It is logical to presume that similar success can be achieved by anticancer drugs which work not via two different compounds, but rather by a single compound progressing through two alternate mechanisms at the same time.

In this work, stilbene-fused flavanone (4) and chalcone (5) structures were proposed as potentially biologically active compounds (Fig. 1). The aim of this work is to optimize a synthesis route for the preparation of stilbene-fused flavanones (4) and chalcones (5). Ultimately the goal is to find compounds which have the benefits of both stilbene and chalcones, or the benefits of both stilbene and flavanones.

\section{Results and discussion}

The products, stilbene-fused flavanone (4) or stilbene-fused chalcone (5), can be readily converted to another one in the presence of acids or bases as shown in Fig. 1. Retro-synthetic analysis (Fig. 2), shows that the synthesis of the target compounds requires three steps: Claisen-Schmidt, Heck, and Michael addition reactions.

All of these reactions can be carried out under basic conditions. The noted tolerance of the substituents in these reactions allowed us to attempt the synthesis of the target compounds by two different proposed approaches. The first starts with a Claisen-Schmidt reaction between 3-bromobenzaldehyde and acetophenones to 


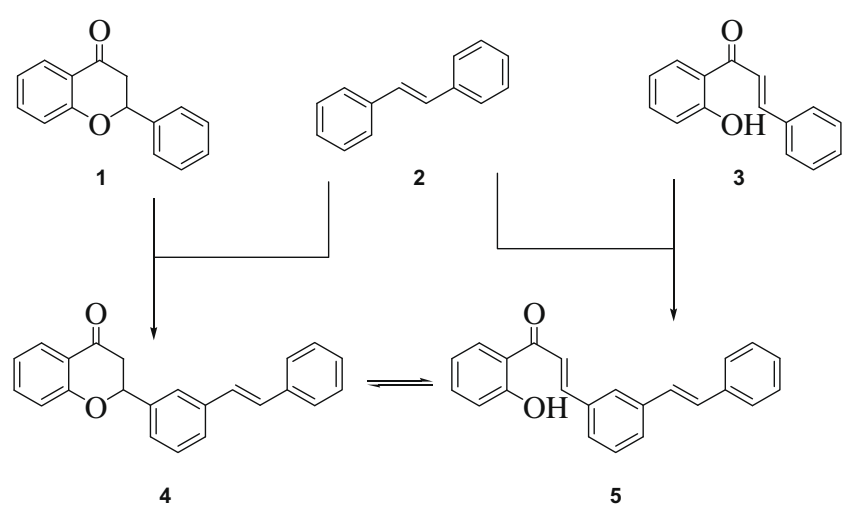

Fig. 1. Structures of flavanone (1), stilbene (2), $2^{\prime}$-hydroxychlacones (3), stilbenefused flavanone (4), and stilbene-fused chalcone (5).
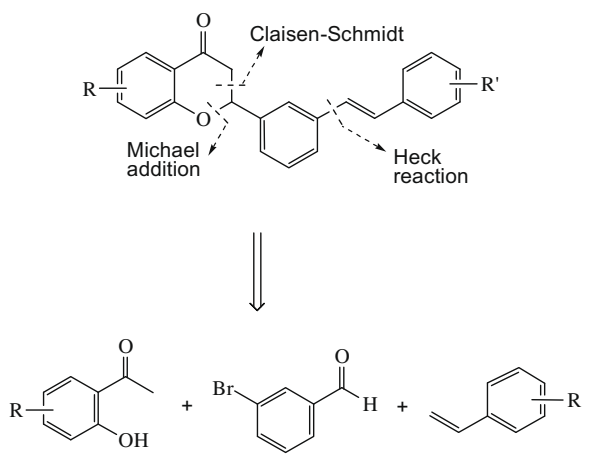

Fig. 2. Retro-synthetic analysis of stilbene-fused flavanones.

form 2'-hydroxy-3-bromochalcone derivatives. Then intramolecular Michael addition reaction would give brominated flavanones, which can be reacted with styrenes in the presence of a palladium catalyst to yield stilbene-fused 2'-hydroxycalcones, which can be transformed to corresponding stilbene-fused chalcones under acidic or basic conditions.

As an alternative second route, synthesis can be initiated with a Heck reaction between 3-bromobenzaldehyde and a styrene derivative to form a trans-stilbene. Then the formed product can be transformed into stilbene-fused 2'-hydroxycalcones and later to stilbene-fused flavanones by sequential Claisen-Schmidt and Michael addition reactions.

Applying the first route, Claisen-Schmidt reactions of different 2-hydroxyacetophenones (6-11) with 3-bromobenzaldehyde (12) were studied as shown in Table 1 . These reactions were performed at room temperature in sodium hydroxide containing ethanol. Condensation reaction between acetophenone $\mathbf{1 1}$ and 3-bromobenzaldehyde (12) was carried out in DMF, and L-proline was used as the catalyst [20]. Except compound 11, all 2-hydroxy acetophenones have electron donating substituents on them. All reactions were monitored by TLC until no difference was observed. Hydroxide catalyzed reactions involving all starting materials, except 2,4dihydroxy-3-methyl acetophenone (10), produced quite high (91$95 \%$ ) isolated yields. Alternatively, the L-proline catalyzed reaction also gave the chalcone $\mathbf{1 8}$ in $15 \%$ yields. At the same time, L-proline also catalyzed the transformation of the 2'-hydroxychlacone into corresponding flavanone with a yield of $21 \%$. Although, L-proline can catalyze both Claisen-Schmidt and Michael addition reactions at the same time, total yields of products was much lower compared with the yield of the hydroxide catalyzed reaction. Hence, the L-proline catalyzed chalcone synthesis route was abandoned for the rest of this work.
Table 1

Synthesis of 2'-hydroxychalcone derivatives (13-18).

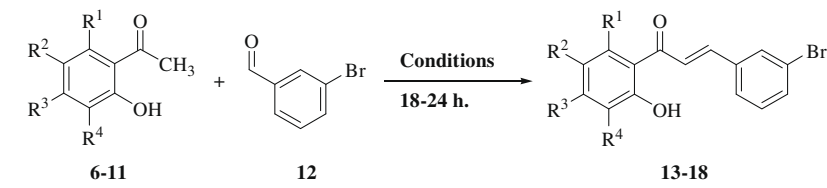

\begin{tabular}{|c|c|c|c|c|c|c|c|}
\hline \multicolumn{5}{|c|}{ Acetophenone } & \multirow[t]{2}{*}{ Conditions } & \multirow[t]{2}{*}{ Product } & \multirow{2}{*}{$\begin{array}{l}\text { Yield } \\
(\%)\end{array}$} \\
\hline & $\mathbf{R}^{1}$ & $\mathbf{R}^{2}$ & $\mathbf{R}^{3}$ & $\mathbf{R}^{4}$ & & & \\
\hline 6 & $\mathrm{H}$ & $\mathrm{OCH}_{3}$ & $\mathrm{H}$ & $\mathrm{H}$ & $\mathrm{NaOH}, \mathrm{EtOH}, \mathrm{RT}$ & 13 & 48 \\
\hline 7 & $\mathrm{H}$ & $\mathrm{Cl}$ & $\mathrm{H}$ & $\mathrm{H}$ & $\mathrm{NaOH}, \mathrm{EtOH}, \mathrm{RT}$ & 14 & 95 \\
\hline 8 & $\mathrm{OCH}_{3}$ & $\mathrm{H}$ & $\mathrm{OCH}_{3}$ & $\mathrm{H}$ & $\mathrm{NaOH}, \mathrm{EtOH}, \mathrm{RT}$ & 15 & 91 \\
\hline 9 & $\mathrm{OCH}_{3}$ & $\mathrm{H}$ & $\mathrm{H}$ & $\mathrm{H}$ & $\mathrm{NaOH}, \mathrm{EtOH}, \mathrm{RT}$ & 16 & 91 \\
\hline 10 & $\mathrm{H}$ & $\mathrm{H}$ & $\mathrm{OH}$ & $\mathrm{CH}_{3}$ & $\mathrm{NaOH}, \mathrm{EtOH}, \mathrm{RT}$ & 17 & NR \\
\hline 11 & $\mathrm{H}$ & $\mathrm{CH}_{3}$ & $\mathrm{H}$ & $\mathrm{NO}_{2}$ & $\begin{array}{l}\text { L-Proline, DMF, } \\
80^{\circ} \mathrm{C}\end{array}$ & 18 & 15 \\
\hline
\end{tabular}

NR: no reaction.

In the next step, cyclization reactions of $2^{\prime}$-hydroxychalcones were studied under acidic and basic conditions. Results of intramolecular Michael addition reactions are summarized in Table 2. For 2 '-hydroxychalcones $(\mathbf{1 3}, \mathbf{1 4}$, and $\mathbf{1 6})$ refluxing acetic acid worked quite well and gave the expected products in high yields (81-90\%). Conversely, the same reaction conditions did not work at all for the dimethoxy-substituted chalcone 15. All attempts to convert chalcone $\mathbf{1 5}$ into flavanone $\mathbf{2 1}$ in refluxing ethanol in the presence of a sodium acetate trihydrate as a mild basic catalyst failed. Later, a similar transformation was successfully achieved for chalcone $\mathbf{1 6}$ in refluxing ethanol containing anhydrous sodium acetate as catalyst. Although the yield for this reaction was almost half of the yields of the acetic acid catalyzed reactions, it was performed under milder conditions, an easier workup procedure, and gave clean TLC results.

In the last step, Heck reactions of synthesized flavanones (19-20) with selected styrenes (23-27) were performed separately in the presence of palladium (II) acetate either with or without the triphenylphosphene ligand. Previously Li and Wang showed that the Heck reaction can successfully produce stilbene when performed in a mixture of $1 \%$ palladium (II) acetate in triethanolamine at $100^{\circ} \mathrm{C}$ in the absence of a ligand [21]. The same procedure was applied to synthesize stilbene-fused flavanones (28-33) in the presence of varying amounts of palladium (II) acetate (first six entries in Table 3). All reactions were monitored by TLC and many

Table 2

Synthesis of flavanone derivatives (19-22).

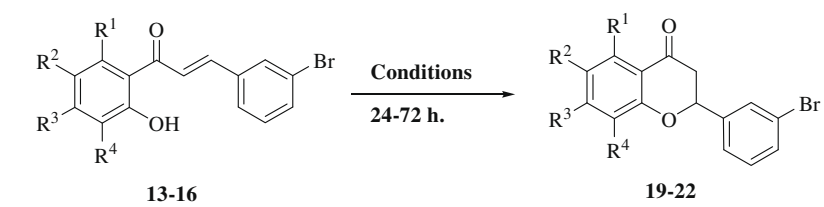

\begin{tabular}{|c|c|c|c|c|c|c|c|}
\hline \multicolumn{5}{|c|}{$2^{\prime}$-Hydroxychalcone } & \multirow[t]{2}{*}{ Conditions } & \multirow[t]{2}{*}{ Product } & \multirow{2}{*}{$\begin{array}{l}\text { Yield } \\
(\%)\end{array}$} \\
\hline & $\mathbf{R}^{1}$ & $\mathbf{R}^{2}$ & $\mathbf{R}^{3}$ & $\mathbf{R}^{4}$ & & & \\
\hline 13 & $\mathrm{H}$ & $\mathrm{OCH}_{3}$ & $\mathrm{H}$ & $\mathrm{H}$ & Acetic acid, reflux & 19 & 81 \\
\hline 14 & $\mathrm{H}$ & $\mathrm{Cl}$ & $\mathrm{H}$ & $\mathrm{H}$ & Acetic acid, reflux & 20 & 90 \\
\hline 15 & $\mathrm{OCH}_{3}$ & $\mathrm{H}$ & $\mathrm{OCH}_{3}$ & $\mathrm{H}$ & Acetic acid, reflux & 21 & NR \\
\hline 16 & $\mathrm{OCH}_{3}$ & $\mathrm{H}$ & $\mathrm{H}$ & $\mathrm{H}$ & Acetic acid, reflux & 22 & 90 \\
\hline 16 & $\mathrm{OCH}_{3}$ & $\mathrm{H}$ & $\mathrm{H}$ & $\mathrm{H}$ & $\mathrm{NaOAc}, \mathrm{EtOH}$, reflux & 22 & 45 \\
\hline 15 & $\mathrm{OCH}_{3}$ & $\mathrm{H}$ & $\mathrm{OCH}_{3}$ & $\mathrm{H}$ & $\begin{array}{l}\mathrm{NaOAc} \cdot 3 \mathrm{H}_{2} \mathrm{O}, \mathrm{EtOH} \text {, } \\
\text { reflux }\end{array}$ & 21 & NR \\
\hline
\end{tabular}

NR: no reaction. 
Table 3

Attempts to synthesize stilbene-fused flavanones (28-34) from bromoflavanones (19 and 20).

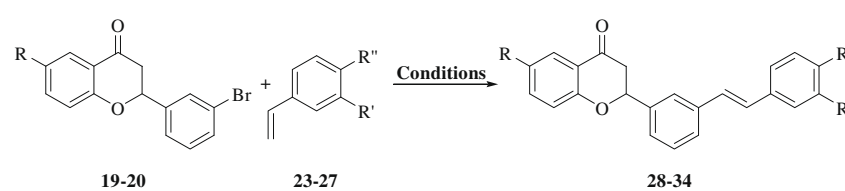

\begin{tabular}{|c|c|c|c|c|c|c|c|}
\hline \multicolumn{2}{|c|}{ Flavanone } & \multicolumn{3}{|c|}{ Stilbene } & \multirow[t]{2}{*}{ Conditions } & \multirow[t]{2}{*}{ Product } & \multirow{2}{*}{$\begin{array}{l}\text { Yield } \\
(\%)\end{array}$} \\
\hline & $\mathrm{R}$ & & $\mathrm{R}^{\prime}$ & $\mathrm{R}^{\prime \prime}$ & & & \\
\hline 19 & $\mathrm{OCH}_{3}$ & 23 & $\mathrm{H}$ & $\mathrm{OCH}_{3}$ & $\begin{array}{l}\text { 12\% } \mathrm{Pd}(\mathrm{OAc})_{2}, \\
\mathrm{~N}\left(\mathrm{C}_{2} \mathrm{H}_{4} \mathrm{OH}\right)_{3}, 10 \mathrm{~h}\end{array}$ & 28 & 43 \\
\hline 20 & $\mathrm{Cl}$ & 23 & $\mathrm{H}$ & $\mathrm{OCH}_{3}$ & $\begin{array}{l}0,1 \% \mathrm{Pd}(\mathrm{OAc})_{2}, \\
\mathrm{~N}\left(\mathrm{C}_{2} \mathrm{H}_{4} \mathrm{OH}\right)_{3}, 15 \mathrm{~h}\end{array}$ & 29 & IM \\
\hline 19 & $\mathrm{OCH}_{3}$ & 24 & $\mathrm{CH}_{3}$ & $\mathrm{H}$ & $\begin{array}{l}\text { 1\% } \mathrm{Pd}(\mathrm{OAc})_{2}, \\
\mathrm{~N}\left(\mathrm{C}_{2} \mathrm{H}_{4} \mathrm{OH}\right)_{3}, 14 \mathrm{~h}\end{array}$ & 30 & IM \\
\hline 20 & $\mathrm{Cl}$ & 25 & $\mathrm{H}$ & $\mathrm{CH}_{3}$ & $\begin{array}{l}1 \% \mathrm{Pd}(\mathrm{OAc})_{2}, \\
\mathrm{~N}\left(\mathrm{C}_{2} \mathrm{H}_{4} \mathrm{OH}\right)_{3}, 15 \mathrm{~h}\end{array}$ & 31 & IM \\
\hline 19 & $\mathrm{OCH}_{3}$ & 26 & $\mathrm{H}$ & $\mathrm{F}$ & $\begin{array}{l}20 \% \mathrm{Pd}(\mathrm{OAc})_{2}, \\
\mathrm{~N}\left(\mathrm{C}_{2} \mathrm{H}_{4} \mathrm{OH}\right)_{3}, 48 \mathrm{~h}\end{array}$ & 32 & IM \\
\hline 19 & $\mathrm{OCH}_{3}$ & 27 & $\mathrm{H}$ & $\mathrm{NH}_{2}$ & $\begin{array}{l}4 \% \mathrm{Pd}(\mathrm{OAc})_{2} \\
\mathrm{~N}\left(\mathrm{C}_{2} \mathrm{H}_{4} \mathrm{OH}\right)_{3}, 48 \mathrm{~h}\end{array}$ & 33 & IM \\
\hline 19 & $\mathrm{OCH}_{3}$ & 23 & $\mathrm{H}$ & $\mathrm{OCH}_{3}$ & $\begin{array}{l}1 \% \mathrm{Pd}(\mathrm{OAc})_{2}, 2 \% \mathrm{P}(\mathrm{Ph})_{3}, \\
\mathrm{Et}_{3} \mathrm{~N}, \mathrm{CH}_{3} \mathrm{CN} 24 \mathrm{~h}\end{array}$ & 28 & IM \\
\hline 19 & $\mathrm{OCH}_{3}$ & 23 & $\mathrm{H}$ & $\mathrm{OCH}_{3}$ & $\begin{array}{l}1 \% \mathrm{Pd}(\mathrm{OAc})_{2}, 2 \% \mathrm{P}(\mathrm{Ph})_{3} \text {, } \\
\mathrm{Na}_{2} \mathrm{CO}_{3} \text {, Toluene, } 24 \mathrm{~h}\end{array}$ & 28 & IM \\
\hline 19 & $\mathrm{OCH}_{3}$ & 25 & $\mathrm{H}$ & $\mathrm{CH}_{3}$ & $\begin{array}{l}1 \% \mathrm{Pd}(\mathrm{OAc})_{2}, 2 \% \mathrm{P}(\mathrm{Ph})_{3}, \\
\mathrm{Na}_{2} \mathrm{CO}_{3} \text {, Toluene, } 24 \mathrm{~h}\end{array}$ & 34 & IM \\
\hline
\end{tabular}

IM: inseparable mixture.

new spots were seen as an indication of new product formation for all cases. We found it extremely difficult to purify these mixtures.
Table 4

Synthesis of stilbene derivatives (35-39) by ligand free Heck reaction.

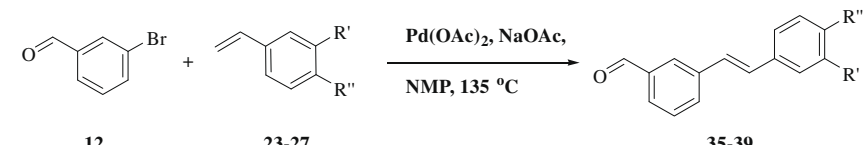

\begin{tabular}{lllll}
\hline Styrene & $\mathrm{R}^{\prime}$ & $\mathrm{R}^{\prime \prime}$ & Product & Yield (\%) \\
\hline $\mathbf{2 3}$ & $\mathrm{H}$ & $\mathrm{OCH}_{3}$ & $\mathbf{3 5}$ & 92 \\
$\mathbf{2 5}$ & $\mathrm{H}$ & $\mathrm{CH}_{3}$ & $\mathbf{3 6}$ & 80 \\
$\mathbf{2 4}$ & $\mathrm{CH}_{3}$ & $\mathrm{H}$ & $\mathbf{3 7}$ & 90 \\
$\mathbf{2 6}$ & $\mathrm{F}$ & $\mathrm{H}$ & $\mathbf{3 8}$ & 75 \\
$\mathbf{2 7}$ & $\mathrm{H}$ & $\mathrm{NH}_{2}$ & $\mathbf{3 9}$ & $\mathrm{NR}$ \\
\hline
\end{tabular}

NR: no reaction.

Only compound $\mathbf{2 8}$ was obtained in sufficiently high purity after being applied to many silica gel columns (43\% yield). As discussed earlier, when flavanones were treated with bases, they reached equilibrium with their chalcone counterparts. It might be possible that triethanolamine can cause such a problem.

Alternatively, Heck reactions were performed in the presence of triphenylphosphine as the ligand. Flavanone 19 was reacted with styrenes 23 and $\mathbf{2 5}$ in the presence of 1\% palladium (II) acetate and $2 \%$ triphenylphosphine. Reactions were carried out in either acetonitrile or toluene, and catalyzed by different bases such as triethylamine or potassium carbonate. TLC analyses of these experiments were not different than those of the triethanolamine results. The reactions ended up as inseparable mixtures, making this route not useful. Therefore, further work continued using the alternative route where the Heck reaction was involved in the initial step.

Table 5

Synthesis of stilbene-fused chalcones (41-57). Numbers in parentheses are isolated yields.

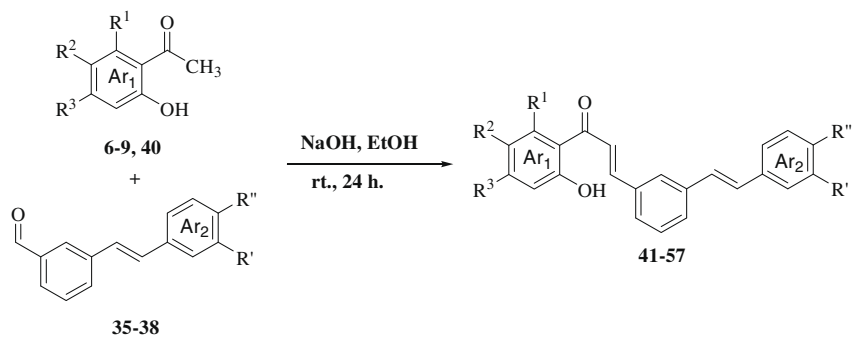

\begin{tabular}{|c|c|c|c|c|}
\hline $\begin{array}{l}\text { Aldehyde }\left(\mathrm{Ar}_{2}\right) \rightarrow \\
\downarrow \text { ketone }\left(\mathrm{Ar}_{1}\right)\end{array}$ & 35 & 36 & 37 & 38 \\
\hline 6 & $41(80 \%)$ & $42(72 \%)$ & $43(10 \%)$ & 44 (57\%) \\
\hline 7 & $45(60 \%)$ & 46 (54\%) & $47(41 \%)$ & $48(23 \%)$ \\
\hline 9 & 49 (55\%) & $50(44 \%)$ & $\mathbf{5 1}(77 \%)$ & $52(77 \%)$ \\
\hline 40 & $53(20 \%)$ & $54^{\mathrm{a}}$ & $55^{\mathrm{a}}$ & $56^{\mathrm{a}}$ \\
\hline 8 & $57(44 \%)$ & & & \\
\hline
\end{tabular}

${ }^{\text {a }}$ Could not be purified from 2-hydroxy-4-methoxyacetophenone (40) on silica gel column. 
Table 6

Synthesis of stilbene-fused flavanones (58-73). Numbers in parentheses are isolated yields.
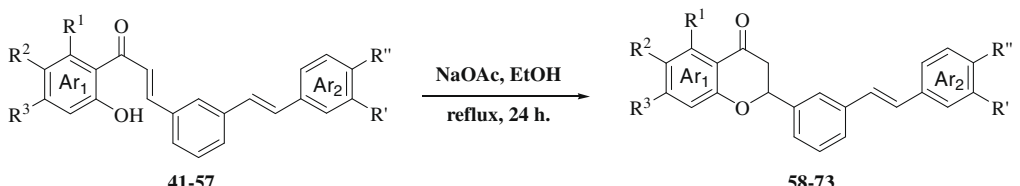

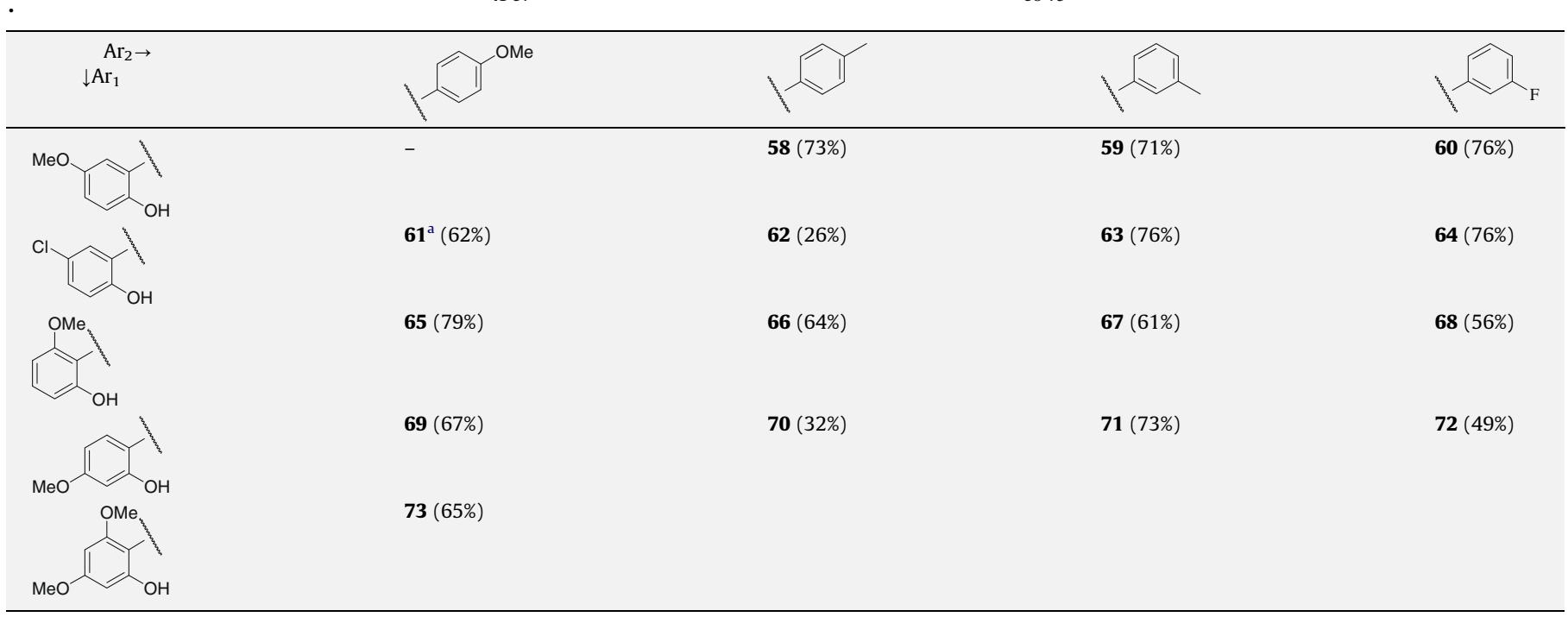

a Conditions of entry 5: potassium tert-butoxide, EtOH, rt, $24 \mathrm{~h}$.

Firstly, Heck reactions between 3-bromobenzaldehyde (12) and commercially available styrenes (23-27) were performed in $\mathrm{N}$ methylpyrrolidone containing palladium (II) acetate $(0.06 \%$ mole) as catalyst and anhydrous sodium acetate as base [22]. Except for the reactant 4-aminostyrene $\mathbf{2 7}$, all styrenes (23-26) gave corresponding stilbenes (35-38) in good yields (Table 4).

Our work involving the first route had allowed us to understand the necessary reaction conditions for the Claisen-Schmidt and Michael addition reactions which could in turn also be applied to the alterative route. Sodium hydroxide in ethanol was used as a reaction medium for the Claisen-Schmidt reactions, while anhydrous sodium hydroxide in refluxing ethanol was used for cyclization reactions. Four commercially available acetophenones $(\mathbf{6}, \mathbf{7}, 9$ and 40 ) and stilbenes (35-38), obtained from Heck reactions, were used to form stilbene-fused chalcones (41-56) and stilbene-fused flavanones (58-72). Yields for these reactions are given in Tables 5 and 6.

As it can be seen from these tables, the yields for transformations from stilbenes (35-38) to stilbene-fused chalcones (41-56) are relatively low because of the difficulties we have met during the purification step. We have found the purification step is extremely difficult for stilbene-fused chalcone products produced from 2-hydroxy-4-methoxy acetophenone (40). Only compound 53 was successfully purified from the unreacted acetophenone $\mathbf{4 0}$. Compounds 54-56 could not be purified at all from their corresponding unreacted acetophenone (40) and they were used as a mixture for the following step.

Cyclization reactions for obtained chalcones (41-56) gave better isolated yields, but difficulties during the purification steps are still present. All products (58-72) were successfully purified from their starting materials. As an alternative, potassium tertbutoxide was used as a base during the preparation of compound 61.

After the synthesis of the $4 \times 4$ matrix of stilbene-fused chalcones (41-56) and flavanones (58-72) were completed, synthesis of one more stilbene-fused flavanone (73) was performed under the same reaction conditions to show the applicability of the route. Synthesis of compound $\mathbf{7 3}$ was successfully done at an overall yield of $29 \%$ for the two steps (Tables 5 and 6 ).

\section{Conclusions}

In conclusion, synthesis of two small matrices $(4 \times 4)$ of stilbene-fused chalcones and flavanones were completed successfully. Work on the biological activities for these matricies is underway and will be reported in a separate paper.

\section{Acknowledgments}

We are grateful to Mrs. Işın Özçelik and Dr. Ritchie Eanes for their kind help with the NMR experiments and manuscript proofreading, respectively. This work was supported by DPT Research Grant DPT-2003K120690 (DPT10) awarded by the State Planning Organization of the Republic of Turkey.

\section{Appendix A. Supplementary material}

Supplementary data associated with this article can be found, in the online version, at doi:10.1016/j.bioorg.2010.04.001.

\section{References}

[1] J. Chong, A. Poutaraud, P. Hugueney, Plant Sci. 177 (2009) 143.

[2] D.S. Seigler, Plant Secondary Metabolism, Kluwer Academic Publishers, Dordrecht, The Netherlands, 1995. p. 140, 156.

[3] E. Tripoli, M. La Guardia, S. Giammanco, D. Di Majo, M. Giammanco, Food Chem. 104 (2007) 466-479.

[4] L.M. Ni, C.Q. Meng, J.A. Sikorski, Expert Opin. Ther. Patents 14 (2004) 16691691.

[5] J.R. Dimmock, D.W. Elias, M.A. Beazely, N.M. Kandepu, Curr. Med. Chem. 6 (1999) 1125-1149.

[6] B. Ahcene, R. Xavier, B. Jean, A. Boumendjel, X. Ronot, J. Boutonnat, Current Drug Targets 10 (2009) 363-371.

[7] F. Wolter, J. Stein, Drugs Future 27 (2002) 949-959. 
[8] C.R. Andrighetti-Fröhner, K.N. de Oliveira, D. Gaspar-Silva, L.K. Pacheco, A.C Joussef, M. Steindel, C.M.O. Simoes, A.M.T. de Souza, U.O. Magalhaes, I.F. Afonso, C.R. Rodrigues, R.J. Nunes, H.C. Castro, Eur. J. Med. Chem. 44 (2009) 755-763.

[9] S.V.M. Jain, K. Kaur, P. Patil, S.R. Patel, R. Jain, Med. Res. Rev. 27 (2007) 65-107.

[10] C. Kontogiorgis, M. Mantzanidou, D. Hadjipavlou-Litina, Mini Rev. Med. Chem. 8 (2008) 1224-1242.

[11] Z. Nowakowska, Eur. J. Med. Chem. 42 (2007) 125-137.

[12] J. Mojzis, L. Varinska, G. Mojzisova, I. Kostova, L. Mirossay, Pharmacol. Res. 57 (2008) 259-265.

[13] N.J. Lawrence, A.T. McGown, Curr. Pharm. Des. 11 (2005) 1679-1693.

[14] S. Yahiaoui, C. Fagnere, C. Pouget, J. Buxeraud, A.-J. Chulia, Bioorg. Med. Chem. 16 (2008) 1474-1480.

[15] Y.-C. Hsiao, W.-H. Kuo, P.-N. Chen, H.-R. Chang, T.-H. Lin, W.-E. Yang, Y.-S. Hsieh, S.-C. Chu, Chem. Biol. Interact. 167 (2007) 193-206.
[16] M. Iinuma, M. Ohyama, T. Tanaka, Phytochemistry 38 (1995) 519-525.

[17] M. Sato, H. Tsuchiya, T. Miyazaki, M. Ohyama, T. Tanaka, M. Linuma, Lett. Appl. Microbiol. 21 (1995) 219-222.

[18] R.B. Silverman, The Organic Chemistry of Drug Design and Drug Action, second ed., Elsevier, USA, 2004. pp. 250-253.

[19] R.B. Silverman, The Organic Chemistry of Drug Design and Drug Action, second ed., Elsevier, USA, 2004. p. 327.

[20] S. Chandrasekhar, K. Vijeender, K.V. Reddy, Tetrahedron Lett. 46 (2005) 6991 6993.

[21] H.J. Li, L. Wang, Eur. J. Org. Chem. (2006) 5099-5102.

[22] A.H.M. de Vries, J.M.C.A. Mulders, J.H.M. Mommers, H.J.W. Henderickx, J.G. de Vries, Org. Lett. 5 (2003) 3285-3288. 